\title{
Environmental chemicals targeting thyroid
}

\author{
Thomas R. Zoeller
}

Biology Department and Program in Molecular and Cellular Biology, University of Massachusetts, Amherst, U.S.A.

\begin{abstract}
Thyroid hormones (THs) are required for normal brain and somatic development and for the proper regulation of physiology in both children and adults. Thyroid function is controlled by the dynamic interrelationships between the hypothalamus, the pituitary and the thyroid. These dynamic relationships maintain circulating levels of THs within a narrow range under normal conditions. Normally, there is likely to be a tight relationship between changes in circulating levels of THs and changes in TH action in various target tissues. This relationship is maintained by tissue-level mechanisms that include TH metabolism and transport. Environmental chemicals that interfere with TH signaling mechanisms (Endocrine Disrupting Chemicals, EDCs) may produce adverse effects both in the individual and in a population. Because of the complex nature of the regulation of thyroid function and TH action, the consequences of EDC exposure is also likely to be complex and our ability to understand these effects as well as to screen for potential EDCs must consider this complexity. Specifically, if there are chemicals in the environment that directly interfere with $\mathrm{TH}$ action through their receptors but do not affect circulating TH levels, they would not be identified as thyroid toxicants by currently applied screening methods or by epidemiological studies. The goal of this review is therefore to identify the issues that must be clearly resolved before effective risk assessment can be performed.
\end{abstract}

Key words: Thyroid hormones, Endocrine disruptors, Environmental chemicals, Thyroid toxicants

\section{THE HYPOTHALAMIC PITUITARY THYROID AXIS (HPT) AXIS}

To develop efficient risk assessment strategies for thyroid toxicants, it is important to understand both the normal functioning of the hypothalamic-pi-

Address for correspondence:

Dr. R. Thomas Zoeller, Biology Department, University of Massachusetts Amherst, 611 N Pleasant St., Morrill Science Center, Amherst, MA 01003, Tel.: +1 (413) 545-2088, Fax: +1 (413) 545-3243, E-mail: tzoeller@bio.umass.edu

Received 04-10-09, Revised 20-11-09, Accepted 15-12-09 tuitary-thyroid axis (HPT) and what we know about individual thyroid toxicants. To this end, background information about the HPT axis and its relevance to thyroid toxicology is reviewed here.

Circulating levels of Thyroid Hormones (THs) are maintained within a relatively narrow range ${ }^{1}$ in large part by a negative feedback relationship between circulating levels of THs and those of Thyroid Stimulating Hormone (TSH). THs appear to exert this effect by acting on one subtype of the TH receptor (TR). TRs are encoded by two separate genes, $\alpha$ and $\beta$, the primary transcripts of which are alternatively spliced 
to generate three major products capable of mediating the response to $\mathrm{TH}$; these transcripts - TR $\alpha 1$, TR $\beta 1$, and TR $\beta 2$ - exhibit a very selective spatial and temporal pattern of expression in the developing and adult brain. ${ }^{2-4}$ Interestingly, TR $\beta 2$ is expressed in the pituitary gland ${ }^{5}$ and in the hypothalamic Paraventricular Nucleus (PVN), ${ }^{6}$ and appears to be the predominant mediator of the negative feedback action of TH on TSH. ${ }^{7}$ Thus, if the TR $\beta 2$ isoform is solely or predominantly responsible for the negative feedback actions of TH on the hypothalamus and pituitary, then environmental chemicals that interact with TRs will affect this negative feedback system if, and only if, they interact with the TR $\beta 2$ isoform.

Finally, although circulating levels of thyroid hormones are generally maintained within a narrow range, the range is far narrower for an individual than for the population, ${ }^{1,8}$ and individual genetics is a major contributor defining the set-point around which the HPT axis is regulated. ${ }^{9}$ The variability in measures of thyroid hormones should be considered both in calculating the power of studies designed to identify associations between environmental exposures and $\mathrm{TH}$ signaling ${ }^{8}$ and in interpreting the findings.

The principal pathway of $\mathrm{TH}$ clearance from serum is by conjugation to glucuronic acid or sulfate. ${ }^{10}$ The Constitutive Androstane Receptor (CAR) and the Pregnane X Receptor (PXR) play central roles in the xenobiotic-induced clearance of $\mathrm{T}_{3}$ and $\mathrm{T}_{4}$ and the subsequent ability of environmental chemicals to reduce serum concentrations of these hormones. ${ }^{11}$ Both CAR and PXR are nuclear (orphan) receptors that respond to classes of xenobiotic chemicals and induce the expression of phase I-III enzymes involved in the detoxification and elimination of steroids, bile acids and xenobiotics. ${ }^{12-14}$ Phase I enzymes (the cytochrome P450) largely hydroxylate hydrophobic chemicals (including xenobiotic chemicals and steroid hormones), which can then be further modified by phase II enzymes such as Glucuronyl Transferases (UDPGTs), Glutathione-S-Transferases (GSTs), and Sulfo Transferases (SULTs). These chemical metabolites are then transported across plasma membranes for elimination by phase III transporters such as the Multidrug Resistance-associated Protein 2 (MRP2) and the Multidrug Resistance Protein 1 (MRP1).

\section{MECHANISMS OF INTERACTIONS OF HPT WITH XENOBIOTICS}

Serum half-life of thyroxin $\left(\mathrm{T}_{4}\right)$ is also controlled in part by serum binding proteins. Two important elements of serum $T_{4}$ in humans are its half-life of 7-10 days and its serum concentration of $100 \mathrm{nM} \cdot{ }^{15}$ No other hormone has a half-life this long and few hormones are found in serum at these concentrations. These elements are largely the result of tight noncovalent binding to three principal serum $\mathrm{T}_{4}$-binding proteins, Thyroxin-Binding Globulin (TBG), Transthyretin (TTR) and albumin. The bound $\mathrm{T}_{4}$ is in rapid equilibrium with unbound or "free" $\mathrm{T}_{4}$ that is available for cellular uptake. Because $\mathrm{T}_{4}$ is more avidly bound to these proteins, it has a much longer half-life than $\mathrm{T}_{3}$. Adult male rats do not appear to produce $\mathrm{TBG},{ }^{16}$ but pregnant females and pups produce high levels of TBG. ${ }^{17-19}$ There are chemicals that are well known to displace $\mathrm{T}_{4}$ from serum binding proteins (e.g., Polychlorinated Biphenyls (PCBs) ${ }^{20,21}$ and Polybrominated Diphenyl Ethers (PBDEs). ${ }^{22-24}$

Chemicals that can displace $\mathrm{TH}$ from these binding proteins may cause a very rapid decline in serum hormone levels. For example, salicylate can cause a rapid (within 2 minutes) and dramatic reduction in serum $\mathrm{T}_{4}$ that can be attributed to biliary clearance. ${ }^{25}$ This is also true for environmental chemicals such as PCBs. ${ }^{26}$ Thus, it may well be the combination of the ability of xenobiotics to displace $\mathrm{TH}$ from serum binding proteins and their ability to induce phase I-III enzymes. However, this scenario has not been fully explored.

Recent observations from the Privalsky lab provide valuable information about the regulation of $\mathrm{TH}$ action mediated by TRs. This group is identifying somatic mutations of TRs that are associated with human cancers and studying the consequences of these mutations on TR function. ${ }^{27}$ Their studies indicate that structural changes associated with mutations in the TR can alter transcriptional regulation and DNA recognition. ${ }^{27}$ In addition, mutations in the TR can affect the transcriptional potency of $\mathrm{T}_{3}$ without affecting the affinity of the TR for $\mathrm{T}_{3}{ }^{28}$ These observations are important because they establish a precedent and a strategy for testing the hypothesis that xenobiotic TR ligands might fit imprecisely into the ligand binding 
pocket of the TR - or into an allosteric site - to alter the structure of the TR, causing it to function in ways that are not a simple activation/inhibition but rather a qualitative change, the consequence of which will be difficult to predict.

\section{Role of TH in Development and in Adult Physiology}

Thyroid hormone is essential for normal brain development. This statement is supported by decades of study both in experimental animals and in humans, ${ }^{29}$ though a detailed analysis of this literature is beyond the scope of the current review. Nevertheless, there are several issues that are important to highlight within the framework of thyroid toxicology and these will be developed here.

\section{Idealized Model of the HPT Axis in Development}

A key issue to consider is that the dynamic interactions among hormones and tissues that make up the HPT axis may be altered by exposure to various xenobiotics in ways that are not fully understood. For example, according to an idealized model of the HPT axis, if a xenobiotic chemical causes a decrease in circulating levels of $\mathrm{T}_{4}$, then serum TSH should increase. However, there are a number of chemicals that cause a decrease in serum total and free $T_{4}$ without causing a concomitant increase in serum TSH. One of the best-known examples is that of PCBs. Exposure to the technical mixture Aroclor 1254 causes a significant decrease in serum $\mathrm{T}_{4}$, but does not cause an increase in serum TSH, while the thyroid gland does not show signs of stimulation such as thyrocyte proliferation. ${ }^{30,31}$

The mechanism by which a toxicant can cause a decrease in the circulating level of $\mathrm{T}_{4}$ without affecting serum TSH is not clear. Moreover, it may differ between toxicants that induce this effect. This is a poorly studied area of research but is critical because a large number of chemicals produce such effects. Moreover, failure of the HPT axis to respond in an idealized way makes identification of biomarkers with adverse effects more complicated. For example, the U.S. Environmental Protection Agency (EPA) proposes that the effect of chemical exposure on thyroid histopathology is an important endpoint for a testing program designed to identify thyroid toxicants (http:// www.epa.gov/endo/pubs/assayvalidation/status.htm). However, this is true only for those thyroid toxicants that affect serum TSH and it seems both unwise and premature to assume that if TSH does not increase, serum $\mathrm{T}_{4}$ does not decrease.

\section{Compensation}

Another critical issue is that of compensation. This concept posits that as thyroid hormone (both $\mathrm{T}_{4}$ and $\mathrm{T}_{3}$ ) levels decline, a number of systemic and tissue-level responses are activated which abrogate or ameliorate the consequences of low TH. This concept is extremely important for risk assessment, but despite its implication, it appears to lack empirical support. We also know that $\mathrm{T}_{4}$ metabolism and tissue uptake may represent major elements of compensation, especially in the developing brain. We recently addressed this issue directly but failed to identify evidence for functional compensation to low thyroid hormone in the developing rat brain. ${ }^{32}$ These findings are consistent with a number of studies indicating that very small changes in serum $\mathrm{T}_{4}$ can exert adverse effects on brain development. ${ }^{32}$ The above observations indicate that we may not fully understand the degree to which "compensation" occurs or the conditions under which it occurs.

\section{Complexity of TRs}

There are many factors that we need to understand about the receptors mediating $\mathrm{TH}$ action in the developing brain. Clearly, there are studies that support the hypothesis that different TR isoforms mediate different actions of TH. ${ }^{33-37}$ Moreover, the different TR isoforms have different responses to $\mathrm{T}_{3}{ }^{27,28}$ as well as to different toxicants. ${ }^{38}$ This is of great interest because the consequences of thyroid toxicants that interact with TRs in an isoform-specific manner may well produce a mosaic of effects that do not recapitulate the effects of global hypothyroidism (or hyperthyroidism). ${ }^{39}$

\section{CHEMICALS THAT INTERFERE WITH THE HPT AXIS}

There is a large number of chemicals that have been shown to affect the HPT axis..$^{40,41}$ However, all of these chemicals have been identified as thyroid toxicants because of their ability to reduce circulating levels 
of thyroid hormones. Although it is clear that this is an important/key mechanism of thyroid toxicity, it is not the only mechanism and an increasing number of chemicals have been shown to interfere with the TR directly or with enzymes or transporters that play important roles in mediating $\mathrm{TH}$ action. These issues are highlighted in the classes of chemicals discussed below.

\section{Polychlorinated Biphenyls (PCBs)}

PCBs are a family of industrial compounds consisting of two linked phenyl rings and varying degrees of chlorination, resulting in 209 different "congeners". 42,43 Before their production was banned in the 1970s, over a billion kilograms of PCBs were produced ${ }^{44}$ and they are now persistent and ubiquitous environmental contaminants that are routinely found in samples of human and animal tissues. ${ }^{42,45}$ PCBs are developmental neurotoxins. Schantz and Rice ${ }^{46}$ reviewed this literature for humans prior to 2003 and concluded that, on balance, there was strong evidence indicating that PCB exposure is associated with negative effects on cognitive development. Interestingly, many different neuropsychological strategies have been used to identify effects of PCB exposure on cognitive function, providing additional strength for this conclusion. Several studies published since 2003 provide additional support for the conclusion that PCB are neurotoxic. For example, Stewart et $\mathrm{al}^{47}$ reported that cord blood PCBs were significant predictors of deficits in McCarthy performance at 38 months of age in children enrolled in the Oswego Newborn and Infant Development Project. These relationships were however not observed at 54 months, indicating that functional compensation may occur. In a later study, Stewart et $\mathrm{a}^{48}$ reported a significant negative association between prenatal PCB exposure (cord blood PCBs) and both full scale and verbal IQ in children 9 years old. In addition, this group found that the size of the corpus callosum on MRI images was a significant predictor of the strength of the association between PCB exposure and response inhibition ${ }^{49}$ in children aged 4 years and that this effect was retained in these children at age 9 years. ${ }^{50}$

Hertz-Picciotto et $\mathrm{al}^{51}$ identified a different kind of potential effect of PCB exposure - the negative association between measures of prenatal PCB ex- posure and thymus size in the infant. This observation is important both because there may be a link between the neurodevelopmental effects of PCB exposure and effects on immune development, but also because of considerable potential consequences of immune dysfunction. Finally, this group also identified a unique negative association between a specific hydroxylated PCB metabolite (4-OH-PCB 107) and Mental Developmental Index (MDI) in children at 16 months of age in eastern Slovakia. ${ }^{52}$

An active area of investigation has been on the mechanism(s) by which PCBs may produce neurodevelopmental effects. One mechanism proposed early was that PCBs could interfere with the thyroid system. ${ }^{53}$ Studies of the relationship between PCB body burden and thyroid hormone levels in human populations have produced variable results. This issue has been extensively reviewed previously ${ }^{54,55}$ and will not be repeated here. However, there are several issues that are important to highlight and update. An early observation indicated that people highly contaminated with PCBs that occurred in rice oil ("Yusho" disease) exhibited elevated $\mathrm{T}_{4}$ and $\mathrm{T}_{3}$ with normal levels of TSH when measured over a decade after the accident. ${ }^{56}$ Thus, an industrial accident provides evidence in humans that high levels of PCB exposure are associated with measures of altered thyroid function. Nonetheless, the findings are not consistent with work in animals, which nearly uniformly confirm that PCB exposure causes a reduction in circulating levels of thyroid hormone. An interesting and potentially significant paradox was reported by Goldey et al, ${ }^{57}$ who found that exposure to the technical mixture Aroclor 1254 caused a reduction in serum total and free $\mathrm{T}_{4}$ but did not affect serum TSH. This issue was further developed by Klaassen, ${ }^{30}$ who showed that not only is TSH not raised by A1254 but that the thyroid gland did not exhibit histological features of stimulation by TSH.

Salay and Garabrant ${ }^{58}$ recently reviewed the complexity of this issue and concluded that, among studies they deem strongest, there tends to be an inverse relationship between serum $\mathrm{T}_{3}$ and $\mathrm{T}_{4}$, but not for free $\mathrm{T}_{4}$ or TSH. There is a notable additional observation recently reported. Specifically, birth delivery mode (i.e., vaginal versus cesarean) modified the association between prenatal exposure to PCBs and neonatal 
thyroid hormone measures. ${ }^{59}$ This is an important observation indicating that a number of biological sources of variation may exist that serve to obscure vital relationships between toxicant exposure and thyroid hormone levels.

Because PCB effects on circulating levels of $\mathrm{TH}$ may not accurately reflect an effect on $\mathrm{TH}$ action itself, we initially pursued the hypothesis that PCBs interfere with $\mathrm{TH}$ action in the developing rodent brain producing a state of relative hypothyroidism. Surprisingly, we found that A1254 reduced circulating levels of $\mathrm{T}_{4}$ to below the detection limit for the radioimmunoassay, yet the $\mathrm{TH}$-responsive genes RC3/Neurogranin and Myelin Basic Protein (MBP) were up-regulated as if $\mathrm{T}_{4}$ levels were increased ${ }^{60} \mathrm{To}$ pursue this hypothesis, we developed a mixture of 6 PCB congeners. ${ }^{119}$ In pregnant rats, this mixture reproduced the effect of A1254 in that it significantly decreased serum $\mathrm{T}_{4}$ levels but increased the expression of a TH-responsive gene (malic enzyme). Moreover, we showed that this mixture could enhance transcription through a specific TH response element (a DR4), which minimally required the combination of PCBs 105, 118, and 126. Finally, using pharmacological approaches, we showed that the ability of PCBs to increase TR activity required CYP1A1, indicating that parent PCBs must be hydroxylated to form TR agonists. Interestingly, the PCB metabolite predicted to be formed by CYP1A1 activity is 4-OH-PCB107, which was uniquely associated with Mental Development Index (MDI) by Park et al. ${ }^{120}$

\section{Polybrominated Diphenyl Ethers (PBDEs)}

Polybrominated diphenyl ethers are primarily employed as flame retardants in consumer products to delay ignition and burning of materials. Because they are added to the materials rather than chemically bound, they can leach from the materials into the environment over time and use. ${ }^{62}$ Because of their lipophilicity, PBDEs bioaccumulate and levels of PBDEs in human tissues have exhibited significant increases over the past decade, ${ }^{63}$ including serum, ${ }^{64}$ milk $^{65-69}$ and cord blood. ${ }^{59,62}$ Interestingly, PBDE body burden of North Americans is the highest in the world ${ }^{70}$ with toddlers being exposed to nearly 10 times as much as adults. ${ }^{69}$ Thus, it is clear that PBDEs have made their way into the human population, that
PBDE levels are rising, this indicating continual exposures, and that PBDEs have gained access to human development during fetal ${ }^{71}$ and neonatal life.

Because of the ability of PBDEs to bioaccumulate and because blood levels are increasing, especially in children, it is essential to evaluate their endocrine toxicity. Moreover, their structure - with two halogenated phenyl rings attached by an ether link - is considerably more similar to thyroid hormone than are other known thyroid disruptors like PCBs. Hence, a number of studies have recently evaluated the ability of PBDEs to disrupt thyroid function both in animals and in humans. In rodents, PBDE exposure has been repeatedly found to decrease serum total and free $T_{4}$ and increase serum TSH. ${ }^{72-77}$ These observations are dependent to some extent upon the specific PBDE mixture employed in the study, with the lower brominated compounds appearing more potent in reducing serum thyroid hormone levels. Stoker et a ${ }^{75}$ and Szabo et $\mathrm{al}^{72}$ investigated some of the potential mechanisms by which PBDE exposure may lead to a reduction in circulating levels of thyroid hormone. These studies show that a combination of changes in serum $\mathrm{T}_{4}$ binding, $\mathrm{T}_{4}$ conjugation and elimination, and changes in $\mathrm{T}_{4}$ metabolism by deiodination may all be involved in the pathway by which PBDE exposure may reduce circulating levels of thyroid hormone.

Fewer studies have evaluated the relationship between PBDE exposure and thyroid status in humans. Early work did not reveal a relationship between PBDE body burden and thyroid hormone levels in human serum. ${ }^{71,78}$ These two small studies focused on mother-infant pairs in central Indiana (USA) ${ }^{71}$ and occupational exposure in an electrical recycling plant in Sweden. ${ }^{78}$ More recently, Herbstman et $\mathrm{al}^{59}$ reported on a larger study of mother-infant pairs. This study was enhanced by their background work indicating that delivery mode affects thyroid hormone levels in the infant. ${ }^{79}$ Thus, using this information, they then found that PBDE levels in cord blood at birth were negatively associated with both total and free $T_{4}$ in those babies born by vaginal delivery. In contrast, the stress associated with conditions leading to a cesarean delivery apparently were such that they masked this relationship. This observation is critical first because it indicates that PBDE body burden may produce a stressor on the thyroid system during development and 
second because it indicates that our ability to identify these relationships is dependent upon eliminating variables that can mask this relationship.

Interestingly, several animal studies revealed that PBDE exposure could lower circulating levels of vitamin A. ${ }^{77,80}$ This is noteworthy because retinoic acid signaling is a potentially important co-regulator of gene expression with thyroid hormone signaling. ${ }^{81}$ It is therefore essential to ascertain whether PBDE exposure can potentially reduce the circulating levels of both thyroid hormone and vitamin A. Moreover, the condition of marginal vitamin A deficiency renders rodents significantly more sensitive to the $\mathrm{TH}$-lowering effect of PBDEs. ${ }^{82}$ These novel studies indicate that PBDE exposure may exert independent effects on circulating levels of thyroid hormone and vitamin A, but that the cross-talk between these two signaling systems may be a target of PBDE action.

Limited data also indicate that some PBDEs, or their hydroxylated metabolites, can interact directly with thyroid hormone receptors. Marsh et $\mathrm{a}^{83}$ reported that 4'-hydroxy-1,3,3',5-tetrabromodiphenyl ether could bind to the beta isoform of the TR (TR $\beta 1$ ) with an affinity about 150 -fold lower than that of $T_{3}$. In addition, this hydroxylated PBDE exhibited a 40-fold lower affinity for TR $\alpha 1$ than for TR $\beta 1$. Kojiba et a ${ }^{84}$ have evaluated the ability of a different set of PBDEs and their metabolites to affect the thyroid hormone receptor. In this case, they evaluated the ability of these compounds to affect TR function in transcription assays using $\mathrm{CHO}-\mathrm{K} 1$ cells and a palindromic $\mathrm{TH}$ response element. They found that 4-OH-BDE90 exerted a significant antagonistic effect on TR $\alpha 1$ and TR $\beta 1$ at $10^{-5} \mathrm{M}$. There were no apparent differences between the effects on TR $\alpha 1$ or TR $\beta 1$.

Taken together, these studies indicate that PBDEs are thyroid toxicants that clearly reduce measures of thyroid function in the animal system and for which there is credible evidence for an effect in humans. Moreover, specific PBDE congeners and/or metabolites may affect thyroid hormone binding to its receptor or receptor function directly.

\section{Perchlorate}

Perchlorate is a powerful oxidant used as a rocket propellant, in ordinance, fireworks, airbag deployment systems, and others. ${ }^{85}$ Because of the environmental stability and prevalence of use of perchlorate, it has become a widespread contaminant in drinking and irrigation waters and in food, ${ }^{86}$ such that perchlorate contamination is nearly ubiquitous in the US population. ${ }^{87}$ Experimental studies in humans indicate that the serum half-life of perchlorate is about 8 hours and that an exposure level of about $5.2 \mu \mathrm{g} / \mathrm{kg} /$ day is sufficient to begin to reduce iodide uptake into the thyroid gland.$^{88}$ Because the adult thyroid gland stores a great deal of hormone in the form of iodinated thyroglobulin, it was surprising that Blount et a ${ }^{89}$ found that urinary perchlorate levels were associated with serum TSH in the general population of women (not in men). It is perhaps not surprising that this association was greater in women with urinary iodine below $100 \mu \mathrm{g} / \mathrm{L}$, and stronger still among these women who smoke,${ }^{90}$ since cigarettes contain thiocyanates that also inhibit iodine uptake. Because infants are particularly vulnerable to thyroid hormone insufficiency ${ }^{29}$ and because perchlorate levels are particularly high in breast milk ${ }^{91}$ it is of concern that perchlorate may be affecting $\mathrm{TH}$ signaling in early infant development in some proportion of the US population. ${ }^{92}$

Predicting the consequences of environmental perchlorate exposure on thyroid function and thyroid hormone action reveals several serious weaknesses in our understanding of the thyroid system as we employ this information for risk assessment. Perhaps most importantly, it remains enigmatic that the high-dose short-term human exposure studies of Greer et $\mathrm{a}^{88}$ and Lawrence et al ${ }^{93,94}$ failed to predict the association of low-dose long-term perchlorate exposure reported by Blount et $\mathrm{al}^{89}$ and Steinmaus et al. ${ }^{90}$ The mechanism of perchlorate action on the thyroid system is relatively simple and is believed to be mediated solely by inhibiting iodide uptake into the thyroid gland. ${ }^{95,96}$ As a result, perchlorate is expected to interfere with thyroid function by reducing iodide uptake and, ultimately, thyroid hormone synthesis. Thus, perhaps the single most important lesson to be learned from the study of perchlorate is why early studies did not allow us to identify potential adverse effects of low-dose chronic exposures.

\section{Bisphenol-A}

Bisphenol-A (BPA, 4,40-isopropylidenediphenol) 
is one of the highest volume chemicals produced worldwide. Over 6 billion pounds are produced each year and over 100 tons are released into the atmosphere by yearly production. ${ }^{104}$ This chemical is the primary building block of polycarbonate plastic, but is also found in a large number of consumer products, epoxy resins that coat food cans, and in dental sealants. ${ }^{105,106}$ Howe et al ${ }^{106}$ estimated human consumption of BPA from epoxy-lined food cans alone to be about $6.6 \mathrm{mg} /$ person/day. Several recent reviews have comprehensively discussed the known sources and human exposures to BPA ${ }^{107-110}$ and will not be further explored here. However, it is important to note that BPA is found in serum of pregnant women, in the amniotic fluid of their fetus, in placenta, and in cord serum taken at birth. ${ }^{111,112}$ Finally, it is of considerable interest to highlight a recent study that found a longer than expected retention time for BPA in humans with substantial non-food sources of exposure. ${ }^{108}$ It is thus clear that the human population is ubiquitously exposed to BPA through sources that are incompletely understood.

BPA is also halogenated (brominated or chlorinated) to produce flame retardants. Tetrabromobisphenol-A (TBBPA) is the most commonly used, with over 60,000 tons produced annually. ${ }^{113,114}$ Thomsen et $\mathrm{al}^{115}$ have recently reported that brominated flame retardants, including TBBPA, increased in human serum from 1977 to 1999 with concentrations in adults ranging from 0.4 to $3.3 \mathrm{ng} / \mathrm{g}$ serum lipids, while infants (0-4 years) exhibited serum concentrations that ranged from 1.6 to 3.5 times higher.

Of potential significance is the fact that BPA was shown to bind to the TR acting as an antagonist on gene expression. ${ }^{116}$ Best characterized as a weak estrogen binding to the estrogen receptor with a Ki of approximately $10^{-5} \mathrm{M},{ }^{117,118} \mathrm{BPA}$ binds to and antagonizes $\mathrm{T}_{3}$ activation of the TR with a $\mathrm{Ki}$ of approximately $10^{-4} \mathrm{M}$, but as little as $10^{-6} \mathrm{M}$ BPA significantly inhibits TR-mediated gene activation. Moreover, Moriyama et $\mathrm{al}^{116}$ found that BPA reduced $\mathrm{T}_{3}$-mediated gene expression in culture by enhancing the interaction of the TR with the corepressor N-CoR. Interestingly, Kitamura reported that tetrachloro- and tetrabromobisphenol-A can bind to the TR with a higher affinity than does parent BPA, and that they act as an agonist on the TR when the rat pituitary cell line $\mathrm{GH} 3$ growth is used as an index of thyroid hormone action. ${ }^{119}$ These early studies indicated that BPA could exert a direct action on thyroid hormone signaling through the TR, which complicates our ability to predict the outcome of BPA exposure on thyroid hormone-regulated developmental or physiological endpoints.

These issues have become further complicated by recent in vitro studies showing that BPA is an antithyroid agent in the absence of a canonical Thyroid Response Element (TRE). In general, BPA is identified as an antagonist and the halogenated forms as an agonist, but this is not uniformly observed. Although the active dose of these compounds typically is reported to be in the micromolar range, some effects were reported in the sub-nanomolar range.

Considering these findings in vitro, it is not surprising that actions of BPA on thyroid hormone signaling have also been reported in in vivo assays. Iwamuro $^{129}$ first reported that BPA could block thyroid hormone-induced tail resorption during Xenopus metamorphosis. This report was followed by a study using primary mouse Oligodendrocyte Precursor Cells (OPCs) finding that $10^{-5} \mathrm{M}$ BPA could inhibit $\mathrm{T}_{3}$-induced specification of oligodendrocytes. ${ }^{130} \mathrm{Our}$ lab then found that developmental exposure to BPA in rats produces an endocrine profile similar to that observed in thyroid resistance syndrome. ${ }^{131}$ Specifically, $\mathrm{T}_{4}$ levels were elevated during development in the pups of BPA-treated animals, but TSH levels were not different from controls. This profile is consistent with BPA inhibition of TR $\beta$-mediated negative feedback. By contrast, the TH-response gene RC3 was elevated in the dentate gyrus of these BPA-treated animals. ${ }^{131}$ Because the TR $\alpha$ isoform is expressed in the dentate gyrus, we concluded that BPA may be a selective TR $\beta$ antagonist in vivo. These observations were partly confirmed by Xu et al, ${ }^{132}$ who reported that BPA exposure increased serum free $T_{4}$ in dams and in pups prior to P21. However, they did not observe RC3 expression alteration in the hippocampus. Given that SRC-1 appears to be up-regulated by thyroid hormone in these regions of the hippocampus, ${ }^{133}$ the findings of $\mathrm{Xu}$ et al may indicate either that the BPA-induced increase in free $\mathrm{T}_{4}$ is responsible for increasing SRC-1 expression or that BPA is having this effect directly. Because of the consistent finding that BPA is a TR 
agonist, it seems likely that the former interpretation has the greatest support.

If BPA is a selective TR $\beta$ antagonist in vivo, it is possible that it could produce effects similar to thyroid resistance syndrome in which the TR $\beta$ receptor is defective leading to elevated serum $\mathrm{T}_{4}$ and either normal or slightly elevated TSH. ${ }^{134}$ In this regard, it is potentially important to note that there may be an association between thyroid resistance and attention-deficit hyperactivity disorder (ADHD) in humans ${ }^{101,135,136}$ and in rats. ${ }^{137}$ Therefore, it is possibly significant that BPA-exposed rats exhibit ADHD-like symptoms. ${ }^{138}$ In addition, BPA exposure alters neocortical histogenesis in the mouse. ${ }^{139,140}$ Although no specific link was made to TH action in this study, the findings are consistent with the hypothesis that BPA alters early development of the cortex by interfering with $\mathrm{TH}$ signaling.

These experimental studies provide strong evidence that BPA can interfere with $\mathrm{TH}$ signaling both in vitro and in vivo. However, because of the complex nature of the interaction of BPA (and halogenated derivatives) with the $\mathrm{TH}$ receptor, it is likely to be difficult to identify thyroid disrupting effects of BPA in humans. Despite this, Sugiura-Ogasawara et al ${ }^{141}$ found that BPA exposure was associated with recurrent miscarriage, and early fetal loss associated with both elevated ${ }^{142}$ and reduced ${ }^{143}$ serum $T_{4}$. Thus, considering the widespread exposure of the human population to BPA, it will be of considerable interest to explore the potential relationship between BPA exposure and thyroid disruption.

\section{SUMMARY AND CONCLUSIONS}

Animal studies are revealing both the complexity of the thyroid system and the complexity of the ways in which EDCs may interfere with $\mathrm{TH}$ signaling. A significant conclusion that needs to be drawn from these studies is that the current clinical strategy of evaluating thyroid disease (i.e. measure blood levels of hormones, antibodies and proteins) is not sufficient to identify EDC actions on thyroid hormone signaling that may well be associated with disease in the human population. Moreover - and less defensible - screening and testing strategies to identify thyroid toxicants focus on an extremely limited number of endpoints. ${ }^{144}$ Clearly recent studies of EDC actions on the thyroid system need to be taken into account in both clinical and regulatory studies.

\section{REFERENCES}

1. Andersen S, Pedersen KM, Bruun NH, Laurberg P, 2002 Narrow individual variations in serum T(4) and $\mathrm{T}(3)$ in normal subjects: A clue to the understanding of subclinical thyroid disease. J Clin Endocrinol Metab 87: 1068-1072.

2. Keijzer R, Blommaart PJ, Labruyere WT, et al, 2007 Expression of thyroid hormone receptors $\mathrm{a}$ and $\mathrm{b}$ in developing rat tissues; evidence for extensive posttranscriptional regulation. J Mol Endocrinol 38: 523-535.

3. Bradley DJ, Towle HC, Young WS, 1994 Alpha and beta thyroid hormone receptor (TR) gene expression during auditory neurogenesis: Evidence for TR isoform-specific transcriptional regulation in vivo. Proc Natl Acad Sci USA 91: 439-443.

4. Bradley DJ, Towle HC, Young WS, 1992 Spatial and temporal expression of alpha- and beta-thyroid hormone receptor mRNAS, including the beta- 2 subtype, in the developing mammalian nervous system. J Neurosci 12: 2288-2302.

5. Hodin RA, Lazar MA, Wintman BI, Darling DS, Chin WW, 1989 Identification of a thyroid hormone receptor that is pituitary-specific. Science 244: 76-79.

6. Cook CB, Kakucska I, Lechan RM, Koenig RJ, 1992 Expression of thyroid hormone receptor beta-2 in rat hypothalamus. Endocrinology 130: 1077-1079.

7. Wan W, Farboud B, Privalsky ML, 2005 Pituitary resistance to thyroid hormone syndrome is associated with $\mathrm{T} 3$ receptor mutants that selectively impair beta2 isoform function. Mol Endocrinol 19: 1529-1542.

8. Andersen S, Bruun NH, Pedersen KM, Laurberg P, 2003 Biologic variation is important for interpretation of thyroid function tests. Thyroid 13: 1069-1078.

9. Hansen PS, Brix TH, Sorensen TI, Kyvik KO, Hegedus L, 2004 Major genetic influence on the regulation of the pituitary-thyroid axis: A study of healthy Danish twins. J Clin Endocrinol Metab 89: 1181-1187.

10. Kelly GS, 2000 Peripheral metabolism of thyroid hormones: A review. Altern Med Rev 5: 306-333.

11. Kretschmer XC, Baldwin WS, 2005 CAR and PXR: Xenosensors of endocrine disrupters? Chem Biol Interact 155: 111-128.

12. Honkakoski P, Zelko I, Sueyoshi T, Negishi M, 1998 The nuclear orphan receptor CAR-retinoid X receptor heterodimer activates the phenobarbital-responsive enhancer module of the CYP2B gene. Mol Cell Biol 18: 5652-5658.

13. Ueda A, Hamadeh HK, Webb HK, et al, 2002 Diverse roles of the nuclear orphan receptor CAR in regulating hepatic genes in response to phenobarbital. Mol Phar- 
macol 61: 1-6.

14. Rosenfeld JM, Vargas RJr, Xie W, Evans RM, 2003 Genetic profiling defines the xenobiotic gene network controlled by the nuclear receptor pregnane $\mathrm{x}$ receptor. Mol Endocrinol 17: 1268-1282.

15. Schussler GC, 2000 The thyroxine-binding proteins. Thyroid 10: 141-149.

16. Savu L, Vranckx R, Maya M, Gripois D, Blouquit MF, Nunez EA, 1989 Thyroxine-binding globulin and thyroxine-binding prealbumin in hypothyroid and hyperthyroid developing rats. Biochim Biophys Acta 992: 379-384.

17. Vranckx R, Savu L, Maya M, Nunez EA, 1990 Characterization of a major development-regulated serum thyroxine-binding globulin in the euthyroid mouse. Biochem J 271: 373-379.

18. Vranckx R, Rouaze M, Savu L, Nunez EA, Beaumont C, Flink IL, 1990 The hepatic biosynthesis of rat thyroxine binding globulin (TBG): Demonstration, ontogenesis, and up-regulation in experimental hypothyroidism. Biochem Biophys Res Commun 167: 317-322.

19. Vranckx R, Savu L, Nunez EA, 1989 The microheterogeneity of rat TBG. FEBS letters 244: 343-346.

20. Meerts IA, van Zanden JJ, Luijks EA, et al, 2000 Potent competitive interactions of some brominated flame retardants and related compounds with human transthyretin in vitro. Toxicol Sci 56: 95-104.

21. Chauhan KR, Kodavanti PR, McKinney JD, 2000 Assessing the role of ortho-substitution on polychlorinated biphenyl binding to transthyretin, a thyroxine transport protein. Toxicol Appl Pharmacol 162: 10-21.

22. Richardson VM, Staskal DF, Ross DG, Diliberto JJ, DeVito MJ, Birnbaum LS, 2008 Possible mechanisms of thyroid hormone disruption in mice by BDE 47, a major polybrominated diphenyl ether congener. Toxicol Appl Pharmacol 226: 244-250.

23. Harju M, Hamers T, Kamstra JH, et al, 2007 Quantitative structure-activity relationship modeling on in vitro endocrine effects and metabolic stability involving 26 selected brominated flame retardants. Environ Toxicol Chem 26: 816-826.

24. Meerts IATM, Marsh G, Leeuwen-Bol I, et al, 1998 Interaction of polybrominated diphenyl ether metabolites (PBDE-OH) with human transthyretin in vitro. Organohalogen Compounds 37: 309-312.

25. Langer P, Kokesova H, Michajlovskij N, Gschwendtova K, Hrcka R, Bukovska M, 1977 Rapid disappearance of loading doses of thyroxine from blood and their excretion by the bile in rats. Acta Endocrinol (Copenh) 85: 531-540.

26. Bastomsky CH, 1974 Effects of a polychlorinated biphenyl mixture (aroclor 1254) and DDT on biliary thyroxine excretion in rats. Endocrinology 95: 1150-1155.

27. Chan IH, Privalsky ML, 2006 Thyroid hormone receptors mutated in liver cancer function as distorted antimorphs. Oncogene 25: 3576-3588.

28. Rosen MD, Privalsky ML, 2009 Thyroid hormone re- ceptor mutations found in renal clear cell carcinomas alter corepressor release and reveal helix 12 as key determinant of corepressor specificity. Mol Endocrinol 23: 1183-1192.

29. Zoeller RT, Rovet J, 2004 Timing of thyroid hormone action in the developing brain: Clinical observations and experimental findings. J Neuroendocrinol 16: 809818.

30. Klaassen CD, Hood AM, 2001 Effects of microsomal enzyme inducers on thyroid follicular cell proliferation and thyroid hormone metabolism. Toxicol Pathol 29: 34-40.

31. Hood A, Hashmi R, Klaassen CD, 1999 Effects of microsomal enzyme inducers on thyroid-follicular cell proliferation, hyperplasia, and hypertrophy. Toxicol Appl Pharmacol 160: 163-170.

32. Sharlin DS, Gilbert ME, Taylor MA, Ferguson DC, Zoeller RT, 2010 The nature of the compensatory response to low thyroid hormone in the developing brain. J Neuroendocrinol [Epub ahead of print].

33. Bernal J, 2007 Thyroid hormone receptors in brain development and function. Nat Clin Pract Endocrinol Metab 3: 249-259.

34. Quignodon L, Legrand C, Allioli N, et al, 2004 Thyroid hormone signaling is highly heterogeneous during preand postnatal brain development. J Mol Endocrinol 33: 467-476.

35. Manzano J, Morte B, Scanlan TS, Bernal J, 2003 Differential effects of triiodothyronine and the thyroid hormone receptor beta-specific agonist GC-1 on thyroid hormone target genes in the brain. Endocrinology 144: 5480-5487.

36. Guadano-Ferraz A, Benavides-Piccione R, Venero C, et al, 2003 Lack of thyroid hormone receptor alpha1 is associated with selective alterations in behavior and hippocampal circuits. Mol Psychiatry 8: 30-38.

37. Bernal J, Guadano-Ferraz A, Morte B, 2003 Perspectives in the study of thyroid hormone action on brain development and function. Thyroid 13: 1005-1012.

38. Zoeller RT, 2007 Environmental chemicals impacting the thyroid: Targets and consequences. Thyroid 17: 811817.

39. Zoeller RT, 2003 Thyroid toxicology and brain development: Should we think differently? Environ Health Perspect 111: A628.

40. Brucker-Davis F, 1998 Effects of environmental synthetic chemicals on thyroid function. Thyroid 8: 827-856.

41. Howdeshell KL, 2002 A model of the development of the brain as a construct of the thyroid system. Environ Health Perspect 110: Suppl 3: 337-348.

42. Tilson HA, Kodavanti PRS, 1997 Neurochemical effects of polychlorinated biphenyls: An overview and identification of research needs. NeuroToxicology 13: 727-744.

43. Erickson MD 2001 PCB properties, uses, occurrence, and regulatory history; in Robertson LW, Hansen LG (eds): PCBs: Recent advances in environmental toxicol- 
ogy and health effects. Lexington, KY, The University Press of Kentucky; pp xii-xxx.

44. Erickson MD 1986 Analytical chemistry of PCBs. Boston, Butterworth.

45. Tilson HA, Jacobson JL, Rogan WJ, 1990 Polychlorinated biphenyls and the developing nervous system: Cross-species comparison. Neuro Toxicology 13: 139-148.

46. Schantz SL, Widholm JJ, Rice DC, 2003 Effects of PCB exposure on neuropsychological function in children. Environ Health Perspect 111: 357-576.

47. Stewart PW, Reihman J, Lonky EI, Darvill TJ, Pagano J, 2003 Cognitive development in preschool children prenatally exposed to PCBs and MEHG. Neurotoxicol Teratol 25: 11-22.

48. Stewart PW, Lonky E, Reihman J, Pagano J, Gump BB, Darvill T, 2008 The relationship between prenatal PCB exposure and intelligence (IQ) in 9-year-old children. Environ Health Perspect 116: 1416-1422.

49. Stewart P, Fitzgerald S, Reihman J, et al, 2003 Prenatal PCB exposure, the corpus callosum, and response inhibition. Environ Health Perspect 111: 1670-1677.

50. Stewart P, Reihman J, Gump B, Lonky E, Darvill T, Pagano J, 2005 Response inhibition at 8 and $91 / 2$ years of age in children prenatally exposed to PCBs. Neurotoxicol Teratol 27: 771-780.

51. Hertz-Picciotto I, Park HY, Dostal M, Kocan A, Trnovec T, Sram R, 2008 Prenatal exposures to persistent and non-persistent organic compounds and effects on immune system development. Basic Clin Pharmacol Toxicol 102: 146-154.

52. Park HY, Park JS, Sovcikova E, et al, 2009 Exposure to hydroxylated polychlorinated biphenyls (OH-PCBs) in the prenatal period and subsequent neurodevelopment in Eastern Slovakia. Environ Health Perspect; In Press (doi: 10.1289/ehp.0900611)

53. Bastomsky CH, 1977 Enhanced thyroxine metabolism and high uptake goiters in rats after a single dose of 2,3,7,8-tetrachlorodibenzo-p-dioxin. Endocrinol 101: 292-296.

54. Gauger KJ, Sharlin DS, Zoeller RT (eds) 2007 Polychlorinated biphenyls as disruptors of thyroid hormone action. In: ed. Champagne-Urbana, University of Illinois Press.

55. Zoeller RT 2001 Polychlorinated biphenyls as disruptors of thyroid hormone action. In Fisher LJ, Hansen L (eds): PCBs: Recent advances in the environmental toxicology and health effects of PCBs. Lexington, University of Kentucky Press; pp, 265-272.

56. Murai K, Okamura K, Tsuji H, et al, 1987 Thyroid function in "Yusho" Patients exposed to polychlorinated biphenyls (PCB). Environ Res 44: 179-187.

57. Goldey ES, Kehn LS, Lau C, Rehnberg GL, Crofton KM, 1995 Developmental exposure to polychlorinated biphenyls (aroclor 1254) reduces circulating thyroid hormone concentrations and causes hearing deficits in rats. Toxicol Appl Pharmacol 135: 77-88.
58. Salay E, Garabrant D, 2009 Polychlorinated biphenyls and thyroid hormones in adults: A systematic review appraisal of epidemiological studies. Chemosphere 74: 1413-1419.

59. Herbstman JB, Sjodin A, Apelberg BJ, et al, 2008 Birth delivery mode modifies the associations between prenatal polychlorinated biphenyl (PCB) and polybrominated diphenyl ether (PBDE) and neonatal thyroid hormone levels. Environ Health Perspect 116: 1376-1382.

60. Zoeller RT, Dowling AL, Vas AA, 2000 Developmental exposure to polychlorinated biphenyls exerts thyroid hormone-like effects on the expression of RC3/neurogranin and myelin basic protein messenger ribonucleic acids in the developing rat brain. Endocrinology 141: 181-189.

61. Guadano-Ferraz A, Escamez MJ, Morte B, Vargiu P, Bernal J, 1997 Transcriptional induction of RC3/neurogranin by thyroid hormone: Differential neuronal sensitivity is not correlated with thyroid hormone receptor distribution in the brain. Brain Res Mol Brain Res 49: 37-44.

62. Frederiksen M, Vorkamp K, Thomsen M, Knudsen LE, 2008 Human internal and external exposure to PBDEs - a review of levels and sources. Int J Hyg Environ Health 212: 109-134.

63. McDonald TA, 2002 A perspective on the potential health risks of PBDEs. Chemosphere 46: 745-755.

64. Sjodin A, Jones RS, Focant JF, et al, 2004 Retrospective time-trend study of polybrominated diphenyl ether and polybrominated and polychlorinated biphenyl levels in human serum from the United States. Environ Health Perspect 112: 654-658.

65. Haraguchi K, Koizumi A, Inoue K, et al, 2009 Levels and regional trends of persistent organochlorines and polybrominated diphenyl ethers in asian breast milk demonstrate pops signatures unique to individual countries. Environment international 35: 1072-1079.

66. She J, Holden A, Sharp M, Tanner M, Williams-Derry C, Hooper K, 2007 Polybrominated diphenyl ethers (PBDEs) and polychlorinated biphenyls (PCBs) in breast milk from the Pacific Northwest. Chemosphere 67: S307317.

67. Jaraczewska K, Lulek J, Covaci A, et al, 2006 Distribution of polychlorinated biphenyls, organochlorine pesticides and polybrominated diphenyl ethers in human umbilical cord serum, maternal serum and milk from Wielkopolska region, Poland. Sci Total Environ 372: 20-31.

68. Inoue K, Harada K, Takenaka K, et al, 2006 Levels and concentration ratios of polychlorinated biphenyls and polybrominated diphenyl ethers in serum and breast milk in Japanese mothers. Environ Health Perspect 114: 1179-1185.

69. Schecter A, Pavuk M, Papke O, Ryan JJ, Birnbaum L, Rosen R, 2003 Polybrominated diphenyl ethers (PBDEs) in U.S. mothers' milk. Environ Health Perspect 111: 1723-1729.

70. Schecter A, Papke O, Tung KC, Joseph J, Harris TR, 
Dahlgren J, 2005 Polybrominated diphenyl ether flame retardants in the U.S. Population: Current levels, temporal trends, and comparison with dioxins, dibenzofurans, and polychlorinated biphenyls. Journal of Occupational and Environmental Medicine/American College of Occupational and Environmental Medicine 47: 199-211.

71. Mazdai A, Dodder NG, Abernathy MP, Hites RA, Bigsby RM, 2003 Polybrominated diphenyl ethers in maternal and fetal blood samples. Environ Health Perspect 111: 1249-1252.

72. Szabo DT, Richardson VM, Ross DG, Diliberto JJ, Kodavanti PR, Birnbaum LS, 2009 Effects of perinatal PBDE exposure on hepatic phase i, phase ii, phase iii, and deiodinase 1 gene expression involved in thyroid hormone metabolism in male rat pups. Toxicol Sci 107: 27-39.

73. Tseng LH, Li MH, Tsai SS, et al, 2008 Developmental exposure to decabromodiphenyl ether (PBDE 209): Effects on thyroid hormone and hepatic enzyme activity in male mouse offspring. Chemosphere 70: 640-647.

74. Darnerud PO, Aune M, Larsson L, Hallgren S, 2007 Plasma PBDE and thyroxine levels in rats exposed to bromkal or BDE-47. Chemosphere 67: S386-392.

75. Stoker TE, Laws SC, Crofton KM, Hedge JM, Ferrell JM, Cooper RL, 2004 Assessment of de-71, a commercial polybrominated diphenyl ether (PBDE) mixture, in the edsp male and female pubertal protocols. Toxicol Sci 78: 144-155.

76. Hallgren S, Darnerud PO, 2002 Polybrominated diphenyl ethers (PBDEs), polychlorinated biphenyls (PCBs) and chlorinated paraffins (CPs) in rats-testing interactions and mechanisms for thyroid hormone effects. Toxicology 177: 227-243.

77. Hallgren S, Sinjari T, Hakansson H, Darnerud PO, 2001 Effects of polybrominated diphenyl ethers (PBDEs) and polychlorinated biphenyls (PCBs) on thyroid hormone and vitamin A levels in rats and mice. Arch Toxicol 75: 200-208.

78. Julander A, Karlsson M, Hagstrom K, et al, 2005 Polybrominated diphenyl ethers-plasma levels and thyroid status of workers at an electronic recycling facility. Int Arch Occup Environ Health 78: 584-592.

79. Herbstman J, Apelberg BJ, Witter FR, Panny S, Goldman LR, 2008 Maternal, infant, and delivery factors associated with neonatal thyroid hormone status. Thyroid 18: 67-76.

80. Ellis-Hutchings RG, Cherr GN, Hanna LA, Keen CL, 2006 Polybrominated diphenyl ether (PBDE)-induced alterations in vitamin $\mathrm{A}$ and thyroid hormone concentrations in the rat during lactation and early postnatal development. Toxicol Appl Pharmacol 215: 135-145.

81. Tagami T, Yamamoto H, Moriyama K, et al, 2009 The retinoid $\mathrm{x}$ receptor binding to the thyroid hormone receptor: Relationship with cofactor binding and transcriptional activity. J Mol Endocrinol 42: 415-428.

82. Ellis-Hutchings RG, Cherr GN, Hanna LA, Keen CL,
2009 The effects of marginal maternal vitamin A status on penta-brominated diphenyl ether mixture-induced alterations in maternal and conceptal vitamin A and fetal development in the Sprague Dawley rat. Birth Defects Res B Dev Reprod Toxicol 86: 48-57.

83. Marsh G, Bergman A, Bladh LG, Gillner M, Jakobsson E, 1998 Synthesis of $\mathrm{p}$-hydroxybromodiphnyl ethers and binding to the thyroid hormone receptor. Organohalogen Compounds 37: 305-308.

84. Kojima H, Takeuchi S, Uramaru N, Sugihara K, Yoshida T, Kitamura S, 2009 Nuclear hormone receptor activity of polybrominated diphenyl ethers and their hydroxylated and methoxylated metabolites in transactivation assays using Chinese hamster ovary cells. Environ Health Perspect 117: 1210-1218.

85. NAS (ed 2005) Health implications of perchlorate ingestion. In: ed. Washington D.C., National Research Council of the National Academies.

86. Murray CW, Egan SK, Kim H, Beru N, Bolger PM, 2008 US Food and Drug Administration's total diet study: Dietary intake of perchlorate and iodine. J Expo Sci Environ Epidemiol 18: 571-580.

87. Blount BC, Valentin-Blasini L, Osterloh JD, Mauldin JP, Pirkle JL, 2007 Perchlorate exposure of the US population, 2001-2002. J Expo Sci Environ Epidemiol 17: 400-407.

88. Greer MA, Goodman G, Pleus RC, Greer SE, 2002 Health effects assessment for environmental perchlorate contamination: The dose response for inhibition of thyroidal radioiodine uptake in humans. Environ Health Perspect 110: 927-937.

89. Blount BC, Pirkle JL, Osterloh JD, Valentin-Blasini L, Caldwell KL, 2006 Urinary perchlorate and thyroid hormone levels in adolescent and adult men and women living in the United States. Environ Health Perspect 114: $1865-1871$.

90. Steinmaus C, Miller MD, Howd R, 2007 Impact of smoking and thiocyanate on perchlorate and thyroid hormone associations in the 2001-2002 National Health and Nutrition Examination Survey. Environ Health Perspect 115: 1333-1338.

91. Pearce EN, Leung AM, Blount BC, et al, 2007 Breast milk iodine and perchlorate concentrations in lactating boston-area women. J Clin Endocrinol Metab 92: 16731677.

92. Ginsberg GL, Hattis DB, Zoeller RT, Rice DC, 2007 Evaluation of the U.S. Epa/oswer preliminary remediation goal for perchlorate in groundwater: Focus on exposure to nursing infants. Environ Health Perspect 115: 361-369.

93. Lawrence J, Lamm S, Braverman LE, 2001 Low dose perchlorate (3 mg daily) and thyroid function. Thyroid 11: 295.

94. Lawrence JE, Lamm SH, Pino S, Richman K, Braverman LE, 2000 The effect of short-term low-dose perchlorate on various aspects of thyroid function. Thyroid 10: 659- 
663.

95. Dohan O, Portulano C, Basquin C, Reyna-Neyra A, Amzel LM, Carrasco N, 2007 The na+/i symporter (nis) mediates electroneutral active transport of the environmental pollutant perchlorate. Proc Natl Acad Sci USA 104: 20250-20255.

96. Wolff J, 1998 Perchlorate and the thyroid gland. Pharmacol Rev 50: 89-105.

97. NRC 2005 Health implications of perchlorate ingestion. Washington D.C., National Academies Press.

98. Crump C, Michaud P, Tellez R, et al, 2000 Does perchlorate in drinking water affect thyroid function in newborns or school-age children? Journal of Occupational and Environmental Medicine/American College of Occupational and Environmental Medicine 42: 603-612.

99. Gibbs JP, Ahmad R, Crump KS, et al, 1998 Evaluation of a population with occupational exposure to airborne ammonium perchlorate for possible acute or chronic effects on thyroid function. J Occup Environ Med 40: 1072-1082.

100.Lamm SH, Doemland M, 1999 Has perchlorate in drinking water increased the rate of congenital hypothyroidism? Journal of Occupational and Environmental Medicine / American College of Occupational and Environmental Medicine 41: 409-411.

101. Vermiglio F, Lo Presti VP, Moleti M, et al, 2004 Attention deficit and hyperactivity disorders in the offspring of mothers exposed to mild-moderate iodine deficiency: A possible novel iodine deficiency disorder in developed countries. J Clin Endocrinol Metab 89: 6054-6060.

102. Versloot PM, Schroder-van der Elst JP, van der Heide D, Boogerd L, 1997 Effects of marginal iodine deficiency during pregnancy: Iodide uptake by the maternal and fetal thyroid. Am J Physiol 273: E1121-1126.

103. Aghini Lombardi FA, Pinchera A, Antonangeli L, et al, 1995 Mild iodine deficiency during fetal/neonatal life and neuropsychological impairment in Tuscany. J Endocrinol Invest 18: 57-62.

104. Burridge E, 2003 Bisphenol-A: Product profile. Eur Chem News 17: 14-20.

105. Lewis JB, Rueggeberg FA, Lapp CA, Ergle JW, Schuster GS, 1999 Identification and characterization of estrogen-like components in commercial resin-based dental restorative materials. Clin Oral Investig 3: 107-113.

106. Howe SR, Borodinsky L, Lyon RS, 1998 Potential exposure to bisphenol-A from food-contact use of epoxy coated cans. Journal of Coatings Technology 70: 69-74.

107. Vandenberg LN, Maffini MV, Sonnenschein C, Rubin BS, Soto AM, 2009 Bisphenol-A and the great divide: A review of controversies in the field of endocrine disruption. Endcr Rev 30: 75-95.

108. Stahlhut RW, Welshons WV, Swan SH, 2009 Bisphenol-A data in NHANES suggest longer than expected half-life, substantial nonfood exposure, or both. Environ Health Perspect 117: 784-789.

109. Vandenberg LN, Hauser R, Marcus M, Olea N, Welshons
WV, 2007 Human exposure to bisphenol-A (BPA). Reprod Toxicol 24: 139-177.

110. vom Saal FS, Hughes C, 2005 An extensive new literature concerning low-dose effects of bisphenol-A shows the need for a new risk assessment. Environ Health Perspect 113: 926-933.

111. Schonfelder G, Wittfoht W, Hopp H, Talsness CE, Paul M, Chahoud I, 2002 Parent bisphenol-A accumulation in the human maternal-fetal-placental unit. Environ Health Perspect 110: A703-707.

112. Ikezuki Y, Tsutsumi O, Takai Y, Kamei Y, Taketani Y, 2002 Determination of bisphenol-A concentrations in human biological fluids reveals significant early prenatal exposure. Hum Reprod 17: 2839-2841.

113. WHO EHC 1997: Flame-retardants: A general introduction. Geneva, Switzerland, World Health Organization.

114. WHO EHC 1995: Tetrabromobisphenol-A and derivatives. Geneva, Switzerland, World Health Organization.

115. Thomsen C, Lundanes E, Becher G, 2002 Brominated flame retardants in archived serum samples from Norway: A study on temporal trends and the role of age. Environ Sci Technol 36: 1414-1418.

116. Moriyama K, Tagami T, Akamizu T, et al, 2002 Thyroid hormone action is disrupted by bisphenol-A as an antagonist. J Clin Endocrinol Metab 87: 5185-5190.

117. Gaido KW, Leonard LS, Lovell S, et al, 1997 Evaluation of chemicals with endocrine modulating activity in yeast-based steroid hormone receptor gene transcription assay. Toxicol Appl Pharmacol 143: 205-212.

118. Krishnan AV, Stathis P, Permuth SF, Tokes L, Feidman D, 1993 Bisphenol-A: An estrogenic substance is released from polycarbonate flasks during autoclaving. Endocrinology 132: 2279-2286.

119. Kitamura S, Jinno N, Ohta S, Kuroki H, Fujimoto N, 2002 Thyroid hormonal activity of the flame retardants tetrabromobisphenol-A and tetrachlorobisphenol-A. Biochem Biophys Res Commun 293: 554-559.

120. Sugiyama S, Miyoshi H, Yamauchi K, 2005 Characteristics of a thyroid hormone responsive reporter gene transduced into a Xenopus laevis cell line using lentivirus vector. Gen Comp Endocrinol 144: 270-279.

121. Furlow JD, Brown DD, 1999 In vitro and in vivo analysis of the regulation of a transcription factor gene by thyroid hormone during Xenopus laevis metamorphosis. Mol Endocrinol 13: 2076-2089.

122. Kudo Y, Yamauchi K, Fukazawa H, Terao Y, 2006 In vitro and in vivo analysis of the thyroid system-disrupting activities of brominated phenolic and phenol compounds in Xenopus laevis. Toxicol Sci 92: 87-95.

123.Jugan ML, Levy-Bimbot M, Pomerance M, TamisierKarolak S, Blondeau JP, Levi Y, 2007 A new bioluminescent cellular assay to measure the transcriptional effects of chemicals that modulate the alpha- 1 thyroid hormone receptor. Toxicol In Vitro 21: 1197-1205.

124.Jung KK, Kim SY, Kim TG, et al, 2007 Differential 
regulation of thyroid hormone receptor-mediated function by endocrine disruptors. Arch Pharm Res 30: 616-623.

125. Okada K, Imaoka S, Hashimoto S, Hiroi T, Funae Y, 2007 Over-expression of protein disulfide isomerase reduces the release of growth hormone induced by bisphenol-A and/or t3. Mol Cell Endocrinol 278: 44-51.

126. Sun H, Shen OX, Xu XL, Song L, Wang XR, 2008 Carbaryl, 1-naphthol and 2-naphthol inhibit the beta-1 thyroid hormone receptor-mediated transcription in vitro. Toxicology 249: 238-242.

127. Heimeier RA, Das B, Buchholz DR, Shi YB, 2009 The xenoestrogen bisphenol-A inhibits postembryonic vertebrate development by antagonizing gene regulation by thyroid hormone. Endocrinology 150: 2964-2973.

128.Sun H, Shen OX, Wang XR, Zhou L, Zhen SQ, Chen XD, 2009 Anti-thyroid hormone activity of bisphenol-A, tetrabromobisphenol-A and tetrachlorobisphenol-A in an improved reporter gene assay. Toxicol In Vitro 23: 950-954.

129. Iwamuro S, Sakakibara M, Terao M, et al, 2003 Teratogenic and anti-metamorphic effects of bisphenol-A on embryonic and larval Xenopus laevis. Gen Comp Endocrinol 133: 189-198.

130. Seiwa C, Nakahara J, Komiyama T, Katsu Y, Iguchi T, Asou H, 2004 Bisphenol-A exerts thyroid-hormonelike effects on mouse oligodendrocyte precursor cells. Neuroendocrinology 80: 21-30.

131.Zoeller RT, Bansal R, Parris C, 2005 Bisphenol-A, an environmental contaminant that acts as a thyroid hormone receptor antagonist in vitro, increases serum thyroxine, and alters RC3/neurogranin expression in the developing rat brain. Endocrinology 146: 607-612.

132. Xu X, Liu Y, Sadamatsu M, et al, 2007 Perinatal bisphenol-A affects the behavior and SRC-1 expression of male pups but does not influence on the thyroid hormone receptors and its responsive gene. Neurosci Res 58: 149-155.

133. Iannacone EA, Yan AW, Gauger KJ, Dowling AL, Zoeller RT, 2002 Thyroid hormone exerts site-specific effects on SRC-1 and NCOR expression selectively in the neonatal rat brain. Mol Cell Endocrinol 186: 49-59.

134. Yen PM, 2003 Molecular basis of resistance to thyroid hormone. Trends Endocrinol Metab 14: 327-333.

135. Siesser WB, Cheng SY, McDonald MP, 2005 Hyperactivity, impaired learning on a vigilance task, and a differential response to methylphenidate in the TRbetaPV knock-in mouse. Psychopharmacology (Berl) 181: 653663.

136. Hauser P, McMillin JM, Bhatara VS, 1998 Resistance to thyroid hormone: Implications for neurodevelopmental research on the effects of thyroid hormone disruptors. Toxicol Ind Health 14: 85-101.

137. Siesser WB, Zhao J, Miller LR, Cheng SY, McDonald MP, 2006 Transgenic mice expressing a human mutant beta1 thyroid receptor are hyperactive, impulsive, and inattentive. Genes Brain Behav 5: 282-297.

138. Ishido M, Masuo Y, Kunimoto M, Oka S, Morita M, 2004 Bisphenol-A causes hyperactivity in the rat concomitantly with impairment of tyrosine hydroxylase immunoreactivity. J Neurosci Res 76: 423-433.

139. Nakamura K, Itoh K, Sugimoto T, Fushiki S, 2007 Prenatal exposure to bisphenol-A affects adult murine neocortical structure. Neurosci Lett 420: 100-105.

140. Nakamura K, Itoh K, Yaoi T, Fujiwara Y, Sugimoto T, Fushiki S, 2006 Murine neocortical histogenesis is perturbed by prenatal exposure to low doses of bisphenol-A. J Neurosci Res 84: 1197-1205.

141. Sugiura-Ogasawara M, Ozaki Y, Sonta S, Makino T, Suzumori K, 2005 Exposure to bisphenol-A is associated with recurrent miscarriage. Hum Reprod 20: 23252329.

142. Anselmo J, Cao D, Karrison T, Weiss RE, Refetoff S, 2004 Fetal loss associated with excess thyroid hormone exposure. JAMA 292: 691-695.

143. Glinoer D, 2006 Miscarriage in women with positive anti-TPO antibodies: Is thyroxine the answer? J Clin Endocrinol Metab 91: 2500-2502.

144. Zoeller RT, Tan SW, 2007 Implications of research on assays to characterize thyroid toxicants. Crit Rev Toxicol 37: 195-210. 